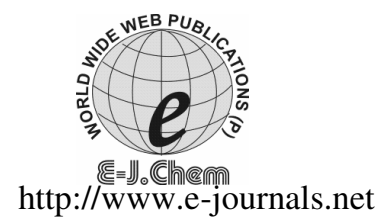

ISSN: 0973-4945; CODEN ECJHAO

E-Journal of Chemistry

2010, 7(1), 215-221

\title{
Determination of Heavy Metals in Fish Tissues, Water and Sediment from Epe and Badagry Lagoons, Lagos, Nigeria
}

\author{
R. A. OLOWU ${ }^{*}$, O. O. AYEJUYO ${ }^{\ddagger}$, G. O. ADEWUYI ${ }^{\#}$, I. A. ADEJORO ${ }^{\#}$, \\ A. A. B. DENLOYE, A. O. BABATUNDE ${ }^{\S}$ and A. L. OGUNDAJO ${ }^{\S}$ \\ ${ }^{* 8}$ Department of Chemistry, \\ Lagos State University (LASU), PMB 1087 Apapa, Lagos, Nigeria. \\ ${ }^{\star}$ Department of Chemistry, University of Lagos, Akoka, Lagos, Nigeria. \\ "Department of Chemistry, University of Ibadan, Nigeria. \\ Department of Zoology, LASU, Nigeria. \\ raade_olowu@yahoo.co.uk
}

Received 17 July 2009; Accepted 10 September 2009

\begin{abstract}
Water samples, sediments, tilapia and cat fishes from each of Epe and Badagry lagoons in Lagos State, Nigeria were analyzed quantitatively for the presence of zinc, nickel and iron using Perking Elmer atomic absorption spectrophotometer. The sediment contains higher concentration of $\mathrm{Fe}$ with a value of $13.30 \mu \mathrm{g} / \mathrm{g}$ against $8.400 \mu \mathrm{g} / \mathrm{g}$ in fishes and $7.30 \mathrm{mg} / \mathrm{L}$ in water. Studies on the different parts of the fish revealed higher concentrations of $4.00 \mu \mathrm{g} / \mathrm{g}$ $\mathrm{Ni}$ on the head of tilapia fish followed by $2.40 \mu \mathrm{g} / \mathrm{g} \mathrm{Ni}$ in the intestine of cat fish. The highest concentration of $1.95 \mu \mathrm{g} / \mathrm{g} \mathrm{Zn}$ was detected on the head of the cat fish while the lowest concentration with a value of $0.16 \mu \mathrm{g} / \mathrm{g}$ was recorded in tilapia head. The concentration of $\mathrm{Zn}$ in the water is within the limits permitted by the Lagos State Environmental Protection Agency (LASEPA) of $1.0 \mathrm{mg} / \mathrm{L} \mathrm{Zn}$ set for water. None of the trace metals investigated was above the maximum permissible level set by world health organization ( WHO).
\end{abstract}

Keywords: Fish tissue, Sediment, Bioaccumulation, Tilapia, Cat fish.

\section{Introduction}

As a commercial hub and the industrial nerve center of Nigeria with an estimated population of more than 20 million people, environmental concerns are normally focused on Lagos State. Over $60 \%$ of Nigeria's industries are cited in the state, each discharging its characteristic range of effluents containing heavy metals into the terrestrial and aquatic 
ecosystems within the state. Typically, the lagoon system in Lagos State is made up of Badagry, Ologe, Lagos, Lekki and Epe lagoons which act as sink or reservoir receiving effluents of over $10,000 \mathrm{~m}^{3}$ daily from drainages through different parts of the metropolis and hinterland $\mathrm{d}^{1,2}$. Expectedly therefore, studies have been conducted on fish which is a highly valued food that contain balance level of amino acid, vitamin $\mathrm{B}_{12}$ cholesterol, high polysaturated fatty and it accounts for $40 \%$ of the animal protein in the diet of Nigerians ${ }^{3}$. Coastal fisheries provide a yearly average of $92.2 \%$ of the total fish production and are dependent on riverine, lagoon and inshore water. Epe and Badagry lagoons are veritable sources of fishery in Nigeria but surprisingly, it has received little attention in heavy metal studies relative to the Lagos Lagoon known widely as a sink for these metals from various industries spread across Lagos State ${ }^{3,4}$. Recent studies have shown for instance that human activities have created ecological pressure on the natural habitat of fish and other marine organism over time. There is an upsurge of interest in water pollution as a result of this deleterious effect. Furthermore, factors such as high population growth accompanied by intensive urbanization, increase in industrial activities and higher exploitation of natural resources including cultivable land have caused pollution increase. There has been a steady increase in discharges that reaches the aquatic environment from industries ${ }^{3}$. Large amount of organic material are released into the water body although some industrial process such as pump mill and sugar processing plant also produce much finely divided organic material as waste product, which is broken down easily by bacteria activities resulting in the reduction of oxygen level or even anaerobic condition in the vicinity of an effluent ${ }^{4,6}$. In addition to direct depletion of oxygen, the decomposition of large quantities of organic material in the water produces inorganic nutrients such as ammonia, nitrate and phosphorus. These enrich the water considerably and give rise to dense algae growth or bloom which can cause the wide daily fluctuations in oxygen described for fish pound and in extreme condition, fish kill can result. This increased productivity caused by excessive organics load can cause a decline in water quality and this symptom of over production is known as eutrophication ${ }^{3,5,7}$.

Sediments have been reported to form the major repository of heavy metal in aquatic system while both allochthonous and autochthonous influences could make a concentration of heavy metals in the water high enough to be of ecological significance ${ }^{3,8-11}$. Bioaccumulation and magnification is capable of leading to toxic level of these metals in fish, even when the exposure is low. The presence of metal pollutant in fresh water is known to disturb the delicate balance of the aquatic ecosystem. Fishes are notorious for their ability to concentrate heavy metals in their muscles and since they play important role in human nutrition, they need to be carefully screened to ensure that unnecessary high level of some toxic trace metals are not being transfer to man through fish consumption ${ }^{11-13}$.

Earlier reports showed that industrial and domestic effluent constitute largest sources of heavy metal which contribute to the steadily increasing metallic contaminant in aquatic and terrestrials environment in most part of the world ${ }^{6,14,15}$. The study of heavy metals and microbial contamination of tilapia specie in Lagos lagoon revealed a higher value in the whole body as well as different parts of the fish than the water samples ${ }^{11,16,17}$.

More studies in the distribution of heavy metals in water bodies reveal that the levels of heavy metals in the bottom sediment are usually higher than in the water columns which shows that sediments acts as sink for heavy metal ${ }^{3,11,18}$.

This paper is geared towards determining the distribution of heavy metal in the fish part, water column and sediments of Epe and Badagry lagoons with the aim of assessing the influence of discharged into the water body through the industries and with a view to establishing a baseline data on the current pollution status of the lagoon environment. 


\section{Experimental}

Sampling was carried out in accordance with the recommendation of UNEP reference method for marine pollution studies ${ }^{11}$. The fish, water and sediment samples were taken from Epe and Badagry following the method already described ${ }^{3}$. The species used for the study are tilapia fish (Tilapia zilli) and cat fish (Chrysichthys nigrodigatatus). Each fish species were caught at Epe and Badagry lagoons using drag net, which were usually left over night in the lagoon by local fishermen. The netted fish were recovered each morning in a picnic box with some quantity of lagoon water to the laboratory. Each fish was properly cleaned by rinsing with distilled water to remove debris planktons and other external adherent. It was then drained under folds of filter, weighed, wrapped in aluminum foil and then frozen at $-10{ }^{\circ} \mathrm{C}$ prior to analysis.

For analysis the fish samples were defrosted for two hours. The scales were removed and each separated into Head, Trunk, Gills and the intestine using plastic knife. The fish parts from the 2 lagoons were dried at $80{ }^{\circ} \mathrm{C}$ for $2 \mathrm{~h}$ in Gallenkamp hot box oven and then blended in an electric moulinex blender.

Approximately $2.0 \mathrm{~g}$ each of sample was weighed and ashed in the furnace at $550{ }^{\circ} \mathrm{C}$ for 90 mins. The ash was dissolved in $5 \mathrm{~mL}$ of concentrated nitric acid and made up to $25 \mathrm{~mL}$ volume. Atomic Absorption Spectrometer was used to determine the presence of zinc nickel and iron.

\section{Sediment samples}

Bottom sediment from each study sites was collected into pre-cleaned polythene bag using a stainless van-ven grab, air dried and then sieved with $200 \mathrm{~mm}$ mesh screen. $5 \mathrm{~g}$ of the sediment were taken into $150 \mathrm{~mL}$ conical flasks. $50 \mathrm{~mL}$ of $0.1 \mathrm{M} \mathrm{HCl}$ was added and the flask was agitated on an orbital shaker for $30 \mathrm{~min}$ at $200 \mathrm{rev} / \mathrm{min}$. The content was filtered into $50 \mathrm{~mL}$ standard flask and made up to mark with $0.1 \mathrm{M} \mathrm{HCl}$ for the determination of zinc, nickel and iron.

\section{Water samples}

Surface water samples were collected using a plastic container. $5 \mathrm{~mL}$ of concentrated hydrochloric acid was added to $250 \mathrm{~mL}$ of water sample and evaporated to $25 \mathrm{~mL}$. The concentrate was transferred to a $50 \mathrm{~mL}$ flask and diluted to mark with distilled water. Metal contents were determined using $304 \mathrm{u} / \mathrm{c}$ Atomic Absorption Spectrometer to determine the presence of zinc nickel and Iron.

\section{Results and Discussion}

\section{Sediment analysis}

The concentration of the trace metals determined in the sediments of Epe lagoon and Badagry lagoon are indicated in Tables $1 \& 2$. Zinc, nickel and iron were detected in the samples with iron having the highest concentration. The high content of iron in the sediment may be because of the clayey material that forms the river bed in the area sampled. This may explain the high concentration recorded in the fish intestine. The fish, being carnivores may have taken the iron from the iron rich bed material along with food which is in an agreement with earlier reports ${ }^{1,11}$

The high concentration recorded in the sediment may be attributed also to human activities such as the discharge of untreated sewage and uses of metals and industrial materials that contain metals as well as the ability of the sediment to act as $\operatorname{sink}^{8,10}$. It has also be reported that iron occurs at high concentration in most Nigeria soils ${ }^{1,8}$. 
Table 1. Metal distribution in Epe Lagoon samples.

\begin{tabular}{|c|c|c|c|c|}
\hline & Samples & $\mathrm{Zn}, \mu \mathrm{g} / \mathrm{g}$ & $\mathrm{Ni}, \mu \mathrm{g} / \mathrm{g}$ & $\mathrm{Fe}, \mathrm{ug} / \mathrm{g}$ \\
\hline \multirow{5}{*}{$\frac{. \frac{\pi}{2}}{\frac{\overrightarrow{0}}{\vec{G}}}$} & Head & 0.16 & 4.00 & 0.11 \\
\hline & Trunk & 0.552 & 2.00 & 0.10 \\
\hline & Tail & 0.95 & 1.20 & 1.84 \\
\hline & Gills & 1.02 & 0.00 & 1.12 \\
\hline & Intestine & 1.29 & 1.20 & 7.20 \\
\hline \multirow{7}{*}{ 吾 } & Head & 1.95 & 1.00 & 0.25 \\
\hline & Trunk & 0.62 & 2.00 & 0.21 \\
\hline & Tail & 0.53 & 2.30 & 2.19 \\
\hline & Gills & 0.73 & 0.80 & 0.89 \\
\hline & Intestine & 1.35 & 2.80 & 6.50 \\
\hline & Sediment & 2.48 & 3.20 & 13.30 \\
\hline & Water & $0.42 \mathrm{mg} / \mathrm{L}$ & $0.60 \mathrm{mg} / \mathrm{L}$ & $7.30 \mathrm{mg} / \mathrm{L}$ \\
\hline
\end{tabular}

Table 2. Metal distribution in Badagry Lagoon samples.

\begin{tabular}{|c|c|c|c|c|}
\hline & Samples & $\mathrm{Zn} \mu \mathrm{g} / \mathrm{g}$ & $\mathrm{Ni} \mu \mathrm{g} / \mathrm{g}$ & $\mathrm{Fe} \mu \mathrm{g} / \mathrm{g}$ \\
\hline \multirow{5}{*}{$\frac{\frac{\pi}{2}}{\frac{\pi}{2}}$} & Head & 0.20 & ND & 0.20 \\
\hline & Trunk & 0.44 & 2.15 & 0.20 \\
\hline & Tail & 1.03 & 1.50 & 2.24 \\
\hline & Gills & 1.30 & ND & 1.32 \\
\hline & Intestine & 0.81 & 1.20 & 8.02 \\
\hline \multirow{7}{*}{ 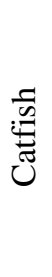 } & Head & 0.25 & ND & 0.35 \\
\hline & Trunk & 0.49 & 0.17 & 0.23 \\
\hline & Tail & 1.05 & 0.009 & 2.29 \\
\hline & Gills & 1.32 & ND & 8.40 \\
\hline & Intestine & 0.89 & ND & 8.40 \\
\hline & Sediment & 1.95 & 2.30 & 11.25 \\
\hline & Water & $0.54 \mathrm{mg} / \mathrm{L}$ & 0.10 & $6.65 \mathrm{mg} / \mathrm{L}$ \\
\hline
\end{tabular}

\section{Fish and water analysis}

The concentrations of metal in the various fish part caught from Epe and Badagry lagoons are shown in the Table $1 \& 2$ respectively. The concentrations of metals in fish indicate the level of metal pollution of the water from which it is caught. In the three major body divisions, the metal found mostly abundant in the fish was iron which ranged between $0.11-6.50 \mu \mathrm{g} / \mathrm{g}$ in Epe lagoon and between 0.20-8.40 $\mu \mathrm{g} / \mathrm{g}$ in Badagry lagoon as shown in the Figure 1 (a-d) which is represented with bar chart. It was found to be more concentrated in the intestine of both fishes from the aquatic environment which may be due to the function of intestine, which serves as the ultimate depository of all substance coming into the fish alimentary canal ${ }^{3,10,11 \text {, }}$. Nickel is the second highest in the level of metals concentration and ranged from N.D-4.00 $\mu \mathrm{g} / \mathrm{g}$ and ranged from N.D-2.30 in Epe lagoon and Badagry lagoon. Zinc ranged from 0.16-1.95 $\mu \mathrm{g} / \mathrm{g}$ and $0.20-1.32 \mu \mathrm{g} / \mathrm{g}$ in Epe and Badagry lagoons respectively. Its however concentrated in the head, gills trunk, tail and intestine. The high concentrations of iron and zinc in the fish parts could be associated with the fact that this metals are naturally abundant in Nigeria soils and since the source of metal depositories are the aquatic system ${ }^{1,8,19}$. 

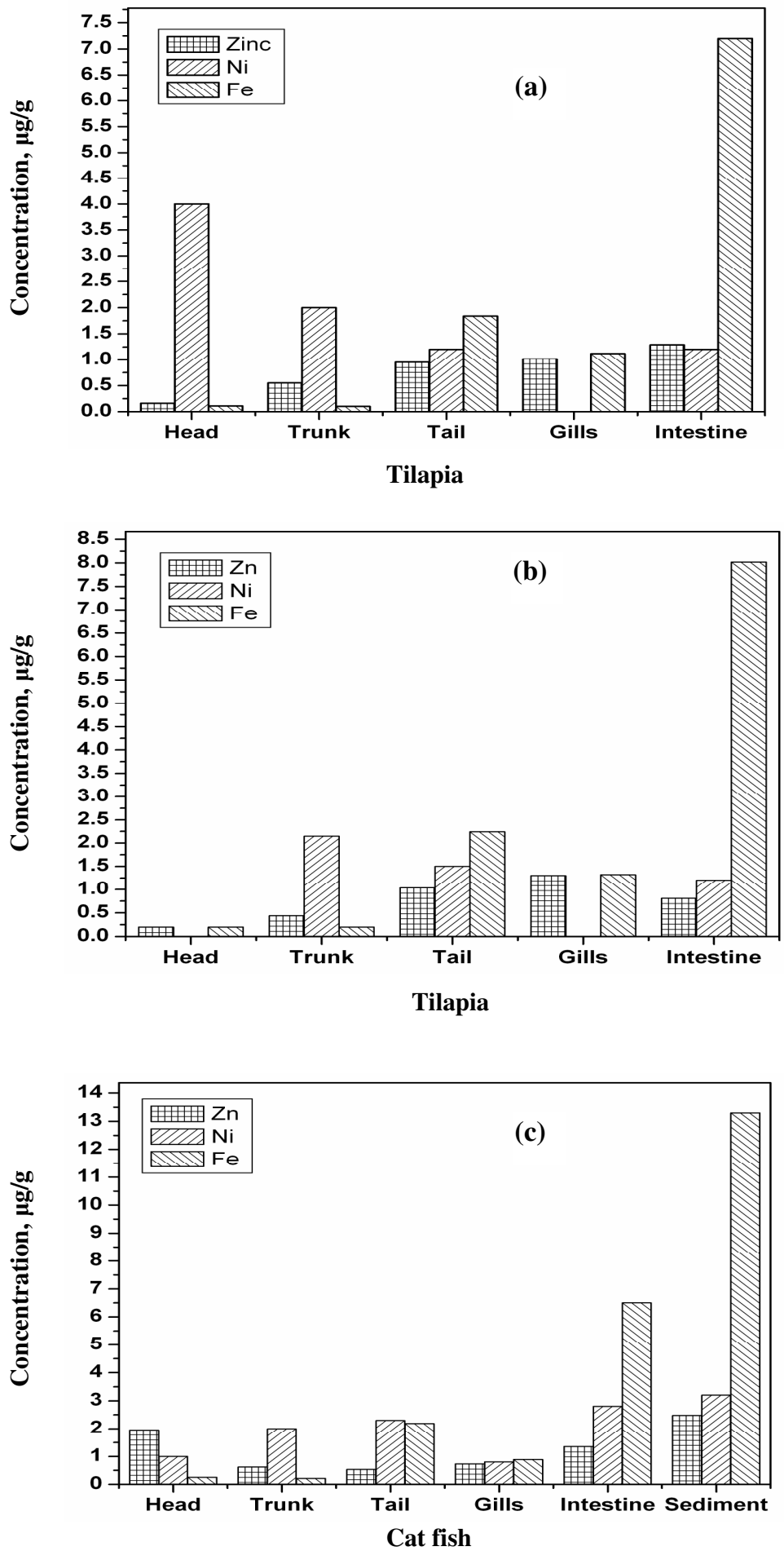


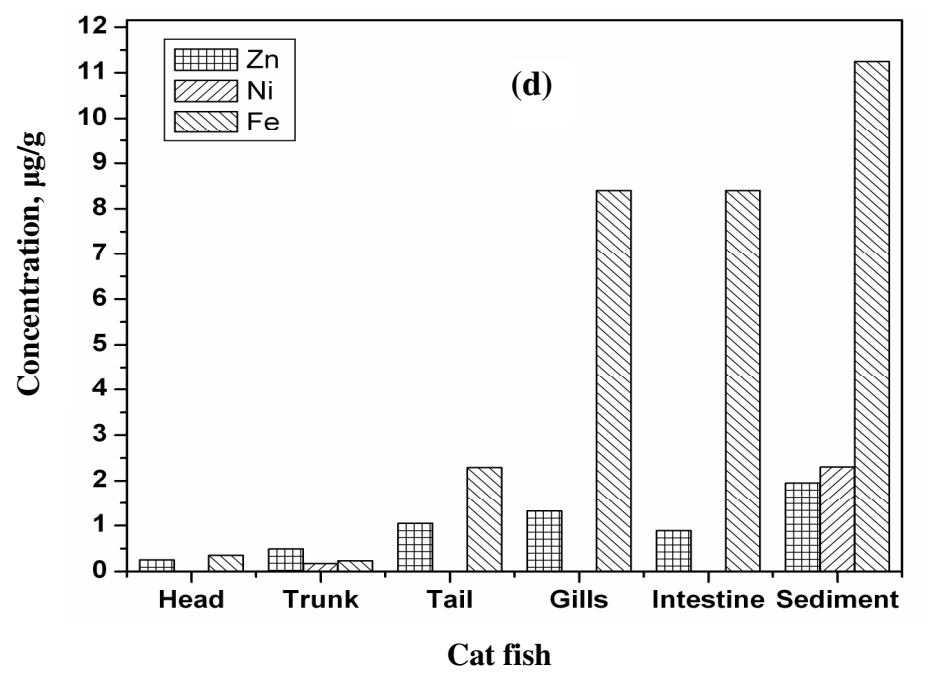

Figure 1. (a) Distribution of heavy metals in tilapia from Epe lagoon, (b) Distribution of heavy metals in tilapia from Badagry lagoon, (c) Distribution of heavy metals in catfish and sediment from Epe lagoon, (d) Distribution of heavy metals in catfish and sediment from Badagry lagoon.

The concentration level in the head and gills could also be attributed to the fact that water always passes through mouth and gill when the water is filtered, this is correlated with the findings of food and agricultural organization ${ }^{11,20,21}$. The significant level of nickel concentration is directly proportional to the size of the fish ${ }^{21}$. Zinc, nickel and iron were detected in the sampled water. Iron has the highest concentration in both samples which is followed by Zinc with a concentration of $0.54 \mathrm{mg} / \mathrm{L}$ in Epe lagoon and $0.40 \mathrm{mg} / \mathrm{L}$ in Badagry lagoon. The level of heavy metal determined in the samples of Epe and Badagry Lagoon are lower than those reported in the sediment which is in agreement with earlier report ${ }^{1,10,11}$. The average values are far less than the United States Environment Protection Agency in Marine water. A comparison of this result with that of the developed countries shows a lower level in the fish studied because the value is below United State for food and drug agency (USFDA) maximum permissible level (MPL) for those metals ${ }^{10,11,22 \text {, }}$. Since the fishes investigated contained trace metals at a concentration below the world health organization. (WHO) standard one may conclude that the level of the metal in the sample analyzed would not constitute any health hazard.

On the basis of this tilapia fish (tilapia Zilli) and cat fish (chryscichthys nogrodigitatus) both from the Epe and Badagry Lagoon may be considered safe for consumption but the need for continuous monitoring to prevent bioaccumulation is necessary ${ }^{1}$.

Going by this result it could be inferred that Epe lagoon is more polluted than Badagry lagoon but both are less polluted than the river Nile in Egypt and Iskenderun bay in Turkey ${ }^{11,21,23}$. The foregoing underscores the low level of metal pollution of Epe and Badagry lagoons and its fisheries resources. It is important that adequate monitoring of the water quality of the rivers should be consistently carried out. Appropriate measure such as legislative provision and other tools for effective and environmental monitoring should be mounted and used with a view to protecting and enhancing the better quality and resources of these Lagoons. 


\section{References}

1. Adefemi S O, Asaolu S S and Olaofe O, Res J Environ Sci., 2008, 2(2), 151-155.

2. Oyewo E O and Don-PedroK N, West Afr J Appl Ecol., 2003, 4, 115-123.

3 Atta M B, Els-sebale L A, Naoman M A and Kassab H, Food Chem., 1997, 58, 1-4.

$4 \quad$ Majolagbe A. O and Bamgbose O, Chem Environ Res., 2007, 16(1-2), 41-51.

5 Payne A I, The Ecology of Tropical Lakes and Rivers: Great Britain: John Wiley and Sons New York, 1986, 32-40.

6. Jibiri N N and Adewuyi G O, Radioprotection, 2008, 43(2), 203-212.

7 Smith V H, Tilman G D and Nekola J C, Environ Pollut., 1999. 100(1-3), 179-196

8 Kakulu S E and Osibanjo O, Nigerian J Chem Soc., 1988, 13, 9-11.

9. Ikem A, Egiebor, N O and Nyavor K, Water Air Soil pollut., 2003, 149, 51-75

10. Benedict C O Okoye, Oladapo A Afolabi and Emmanuel A Ajao, Int J Environ Stud., 1991, 37(1\&2), 35-41.

11. Adeniyi A.A and Yusuf K A, Environ Monit Assess., 2007, 37, 451-458.

12. Mertz. W, The Essential Trace Element, Science, 1981, 213, 1332-1338.

13. Charis K B and Abbasi S A, Int J Environ Stud., 2005, 62, 137-145.

14 Ayodele J T, Momoh R U and Aminu M, Book of Abstract: Second National Environmental Seminar, FEPA, 1991, 14.

15. Oshodi A A and Ipinmoroti K O, Ghana J Chemistry, 1990, 1(2), 138-142.

16. Madanmio X, Maine Pollut bull., 1986, 17(8), 383-385.

17. Kakalu S E, Osibanjo O and Ajayi S O, Environ Int., 1987, 13, 247-251.

18 Chyne-Eng S, Poh Eng S and Tian-Tse A, Maine Pollut bull., 1987, 18(1), 611-612.

19 Nwajei G E and Oruvwuje O, Pak J Sci Ind Res., 2001, 44, 333-337.

20 Bryan G W,Proceeding of the Royal Society London, Ser.,1971, 177, 389-410.

21 Sreenivasa Rao A, Chary N S, Chandra Sekhar K, Kamala C T and Suman Raj D S, Environ Int., 2003, 29, 1001-1008.

22 Odukoya O O and Ajayi S O, Nigeria J Nutritional Science, 1987 ,8(1), 41-49.

23 Yilmaz A B, Environ Res., 2003, 92, 277-281. 


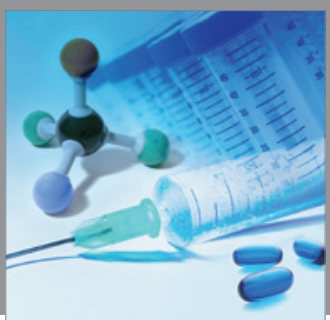

International Journal of

Medicinal Chemistry

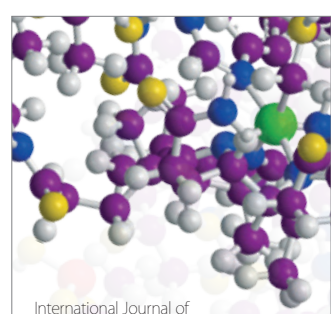

Carbohydrate Chemistry

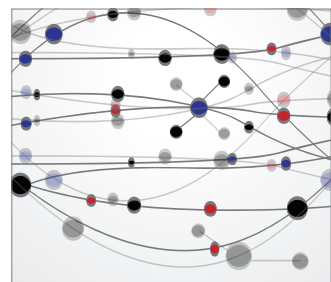

The Scientific World Journal
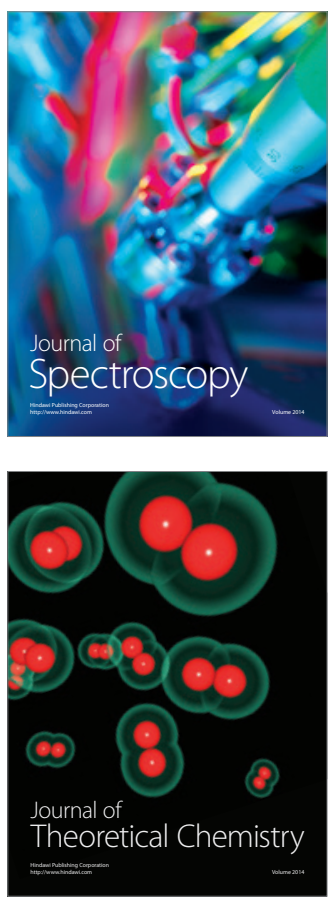
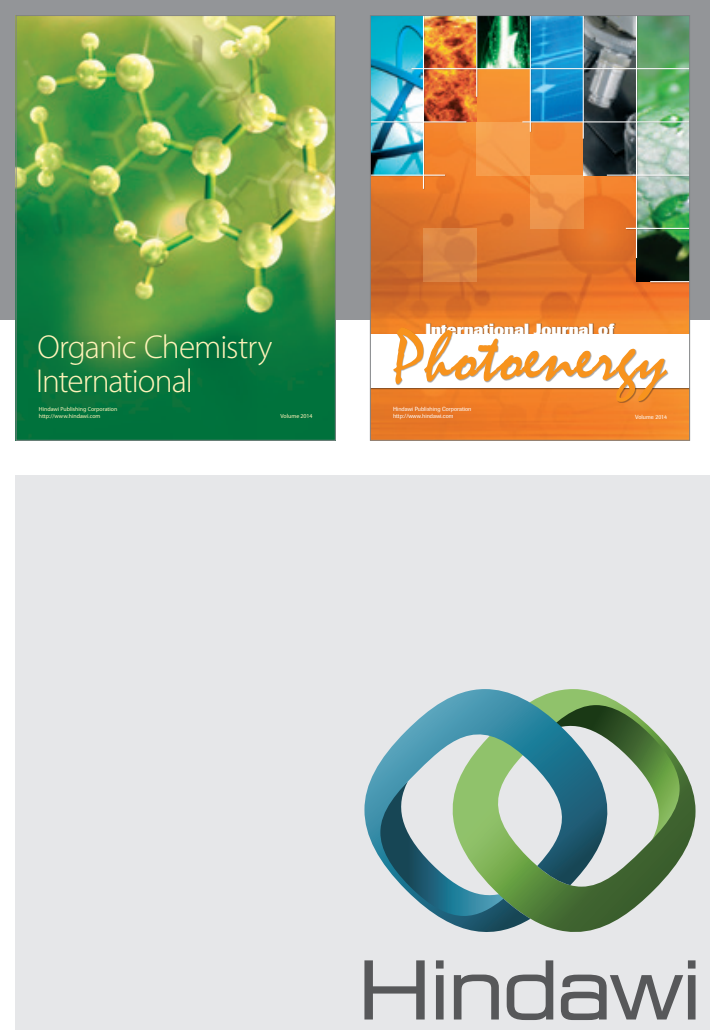

Submit your manuscripts at

http://www.hindawi.com
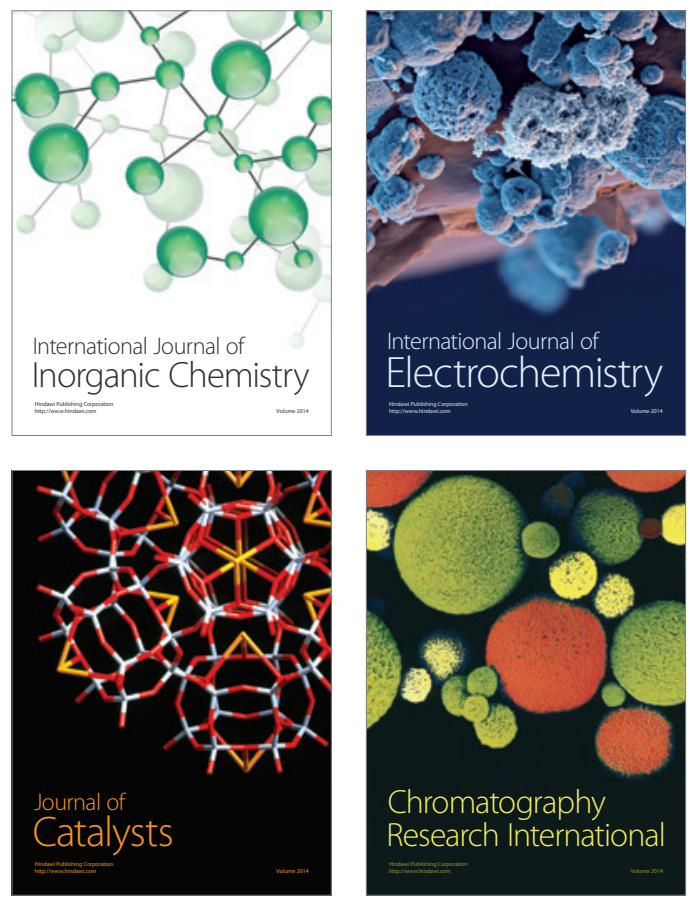
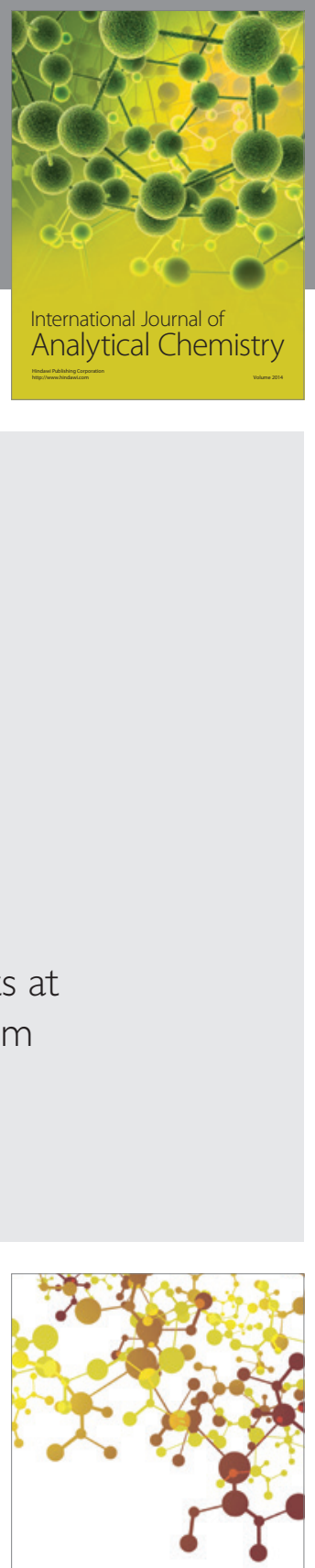

Journal of

Applied Chemistry
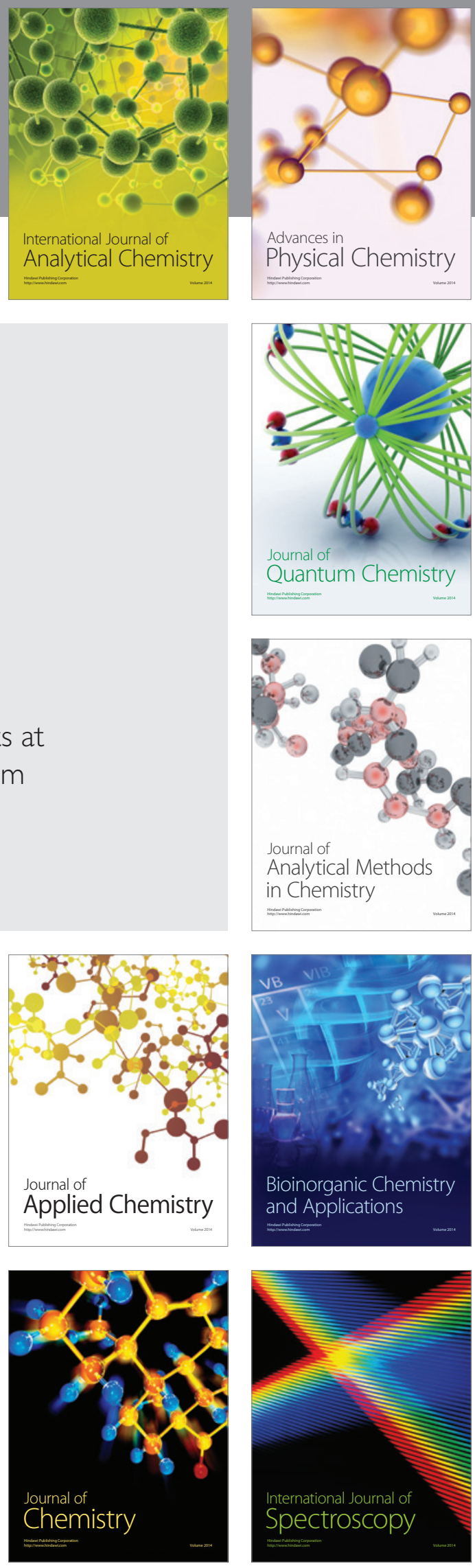